\title{
A brief history of poultry nutrition over the last hundred years
}

\author{
K. ELWINGER ${ }^{1}$, C. FISHER ${ }^{2}$, H. JEROCH ${ }^{3}$, B. SAUVEUR ${ }^{4}$, H. TILLER ${ }^{5}$ and \\ C.C. WHITEHEAD ${ }^{6}$ \% \\ ${ }^{1}$ Swedish University of Agricultural Sciences, Uppsala, Sweden (retired); ${ }^{2}$ AFRC \\ Institute for Grassland and Animal Production, Edinburgh, United Kingdom \\ (retired); ${ }^{3}$ Institute of Agricultural and Nutritional Sciences, Martin Luther \\ University, Halle-Wittenberg, Germany (retired); ${ }^{4}$ INRA Station de Recherches \\ Avicoles, Nouzilly, France (retired); ${ }^{5}$ Lohmann Tierzucht GmbH, Cuxhaven, \\ Germany (retired); ${ }^{6}$ Roslin Institute, Edinburgh, United Kingdom (retired) \\ *Corresponding author: colin.whitehead21@gmail.com
}

The science and practice of poultry nutrition has changed greatly over the last hundred years, moving from a backyard enterprise to the modern computercontrolled production of whole diets formulated to specific nutrient compositions. This has become possible as a result of the identification of individual nutrients and their metabolic roles. Although the word 'protein' was first used in 1834, it was not until the 1950s that the avalanche of research on protein and amino acid requirements of poultry started. Energy content of feeds did not become a consideration until the 1940 s when the concept of metabolisable energy was introduced. The term 'vitamin' was first proposed in 1912 to describe the essentiality of thiamine. The term was later extended to cover other essential compounds needed in small quantities. By the 1940s all the remaining 12 vitamins had been identified, and in the 1970s the importance of the vitamin $D$ metabolites was discovered. The importance of calcium and phosphorus for both growing and laying birds was identified in the early stages of poultry keeping and requirements and dietary ratios were established. More recently, the introduction of feed phytase has allowed lowering of both phosphorus and calcium concentrations. Carbohydrase enzymes have also been development for addition to feeds. The importance of sodium, phosphorus and chloride in maintaining electrolyte balance was identified. Trace minerals were usually supplemented in diets as inorganic salts but organic chelates or proteinates have been found in recent years to be absorbed more efficiently. Antibiotics were widely used as growth promoters but their banning, especially in Europe, has led to the search for alternative additives with growth or health benefits. Poultry nutrition is now a scientifically mature subject but changes in industrial practice can be expected to continue, though probably at a slower pace than in recent years. 
Keywords: history; protein; amino acid; metabolisable energy; vitamins; minerals; enzymes; feed additives

\section{Introduction}

This review has been compiled under the aegis of Working Group 2 (Nutrition) of the European Federation of Branches of WPSA in commemoration of the over 100 years since the founding of WPSA. During this long period, the art and science of nutrition has progressed from a small scale back yard activity to a very large scale industrial one. As the scale of poultry production increased, so did the research effort to sustain it. There was a huge increase in the research effort in the 1940s in USA and in the post Second World War years in Europe. This research effort perhaps reached a peak in the 1970s and has subsequently declined as the science of nutrition has matured.

In USA poultry science departments have been established in universities in many states, all with important nutritional activities. Cornell University was an early leader. In Europe, government funded organisations were established in several countries as the importance of food production increased after WWII. Examples were the ARC Poultry Research Centre (PRC) in UK (at one time with a team of six nutritionists), Het Spelderholt in Netherlands and INRA Station de Recherches Avicoles (SRA) in France. As nutritional science has evolved, many of the poultry science departments in USA have been subsumed within animal science departments, usually with diminished emphasis on poultry, or have disappeared in the case of Cornell. In Europe, reductions in government funding have resulted in the disappearance or merging of some of these institutions within other organisations, sometimes, as in the case in UK, with no current expertise in poultry nutrition. A notable exception is France, where SRA still has an important nutritional component. However, there has been an increase in nutritional research in other countries to establish nutritional conditions under local conditions. Iran has been a notable example.

This progression of nutritional science is perhaps understandable as the main principles of nutrition and roles of individual nutrients were established. The later role of nutrition was mainly to ensure that the needs of the more modern genotypes were met to allow them to reach their greatly increased productive potentials. As nutritional knowledge increased, extension services were established on both sides of the Atlantic to help transfer scientific knowledge into practical application in the industry. Agencies such as the NRC in USA (NRC, 1994) and ARC in UK (ARC, 1975) published booklets detailing the nutrient requirements of poultry. Extension services have now dwindled and the decrease in research into established nutrients has made the updating of traditional nutrient requirements more difficult. It has been left more to the breeders to recommend nutritional specifications for their strains, but there is increasing doubt about the requirements for specific nutrients, particularly vitamins, in current genotypes. Current nutritional research is now supported frequently by commercial organisations, usually with specific emphases in their own products.

The industry has also evolved, particularly in developed countries, with the gradual merger or incorporation of individual farms into very large industrial organisations. This has had an implication for nutritionists, with fewer opportunities for employment in the decreased number of companies. This in turn has led to reductions in poultry science courses at undergraduate level in universities and colleges. Nevertheless, poultry nutrition still assumes huge importance around the world and this is perhaps exemplified by the ever larger attendance at the biennial series of the European Symposium on Poultry 
Nutrition organised by Working Group 2, with delegates coming from all corners of the world.

The following sections describe the main developments in the major nutritional classes over the history of the WPSA. The review is by no means exhaustive, to be so would require a book rather than a journal article, but hopefully will give a flavour of the advances in nutritional science and practice in poultry.

\section{Protein}

The word 'protein' was first used in 1834 (Carpenter, 1994) and the chemistry of amino acids was largely elucidated during the second half of the $19^{\text {th }}$ Century. Thus during the $20^{\text {th }}$ century the scene was set for rapid and extensive developments in the science of protein nutrition. The elucidation of protein quality in terms of amino acid composition, the description of protein foods and consideration of protein requirements and utilisation all saw rapid developments in all animal species and in human nutrition.

When the WPSA was started, the application of these ideas to poultry nutrition was quite advanced but the avalanche of experimental data that characterised the last 50 years or so was only starting to appear. Thus in the $1^{\text {st }}$ World Poultry Congress held in 1921 there are no technical papers referring to protein as such, however in a general paper on nutrition discussed how the relative deficiency of tryptophan in protein would sometimes limit the feeding value of maize. Just three years later in the proceedings of the 2 nd Congress there was a paper describing the protein content of thirty feedstuffs and associated digestibility coefficients, and in the $3^{\text {rd }}$ Congress there was a discussion on both the theoretical and experimental basis of protein requirements. So it seems that the poultry industry was both playing a part in and using the developing ideas about protein nutrition, which at that time were changing rapidly. By 1954 when the first Nutrient Requirements of Poultry was published in America by NAS-NRC (NRC, 1954), in addition to listing crude protein requirements, those for the essential amino acids plus glycine were listed for starting chicks, starting poults and laying hens. In addition the arginine, lysine, methionine, cysteine, tryptophan and glycine contents of a range of poultry feedstuffs were listed.

For a long period, starting in the 1950's, many experiments were described which sought to elucidate the protein and essential amino acid requirements of poultry. This still goes on today. In addition to one or more nutritional variables these experiments considered fixed factors such as species, breed, sex and age of bird and so on. The results were incorporated into tables of nutrient requirements and more recently combined using the methods of meta-analysis (Sauvant et al., 2008). Led by the NAS-NRC publications from America, alternative tables were published in the UK, Australia, France and Brazil and the advisory services of many countries would make recommendations in support of their home industries. Feeding recommendations made by poultry breeding companies and companies selling crystalline amino acids have played an increasingly prominent role in transferring the results of this research to the industry. The latest NAS-NRC tables were published in 1994 (NRC, 1994) and they quote about 440 experiments of this type as the basis of recommending requirements for layer chicks, layers, broilers, broiler breeders, turkeys, turkey breeders, geese ducks, pheasant, Japanese quail and bobwhite quail. The other fixed factor considered is the age of the birds. In 2016 an announcement has just been made that this work is to be updated.

There has been a lot of discussion about the design of such experiments (D'Mello, 2003). Whilst it is preferable that different approaches are used, the one which corresponds most closely to practical feeding situations is the study of balanced 
protein requirements as defined by ideal protein ratios (Lemme, 2003). With four or five essential amino acids now being available for practical feeding it is possible to design balanced protein diets with these amino acids in exact balance and the crude protein level being determined by the most limiting amino acid provided from feed proteins. In addition to the requirement for balanced protein this approach also raises questions about the ideal balance of amino acids, the effects of imbalance and the importance of overall nitrogen supply or the role of non-essential amino acids. All of these topics have featured widely in research and are considered together with information about individual essential amino acids.

The analysis and interpretation of experiments concerned with amino acid requirements is also a topic of importance (Pesti et al., 2009). If a requirement is seen as a point on a curve relating a response to different nutritional inputs then the questions that arise concern the nature of the response, the type of curve used to describe the data and how the requirement point is determined. It is well recognised that different responses, growth, feed efficiency, body composition and perhaps immune status, lead to different estimates of an optimum point on the response curve. The optimum points maybe the maximum response, a selected rate of response or some other objective or subjective criterion. Many years ago, Lerman and Bie (1975) pointed out that an economic response might be the most relevant. This point was reinforced in the context of poultry production by Mack et al. (2000) but is largely ignored.

Analytical methods for the determination of amino acids in foods and feeds and other tissues have developed over a long period of time and the poultry industry has benefitted greatly from these developments. Although now a routine procedure the analyses remain fairly expensive and subject to various sources of error and uncertainty. Thus there is value in building databases of results from different laboratories to provide the best estimates for individual samples of feeds when they are used. This has been pursued most effectively by the companies selling crystalline amino acids. For many raw materials, especially plant proteins, there is value in adjusting amino acid levels for variation in locally determined $\mathrm{N}$-contents. Prediction by rapid methods such as near infrared (NIR) spectroscopy may be of value on a practical basis.

In addition to the content of each feedstuff it is important to know how much of each amino acid from each source is digestible or available to the animal. This topic has also been investigated in many species over a long period of time and a wide variety of experimental methods have been proposed. Because avian species have excreta of mixed faecal and urinary origin the measurement of digestibility of nitrogen compounds is difficult. Thus most progress has been made with indirect bioassays, for example using growth as a measure of availability compared to some standard, and with the measurement of digestibility at points in the tract prior to excretion. In recent years the measurement of digestibility in the distal ileum section of the digestive tract has become a more or less standard procedure for assessing 'availability' of amino acids in poultry (Lemme et al., 2004). This method raises some quite intractable procedural problems involved with digestive markers and the need to correct the results for endogenous secretion of amino acids. However 'standardisation' of basal endogenous amino acid losses using a single reproducible procedure and a reasonable range of digestive markers takes us close to a standard method which can be used to accumulate data of practical value whilst still leaving room for further innovation and improvement.

The sources of protein and amino acids in poultry feeds vary between different countries but are predominantly cereals and cereal by-products, soyabean and, to a much lesser extent, other oilseeds, some re-cycled animal products and synthetic amino acids. Feed enzymes, particularly carbohydrases and phytases, contribute by increasing the digestibility of amino acids in various feed material by eliminating anti- 
nutritional factors. Many plant protein sources contain secondary metabolites which may act as anti-nutritive substances or, in a few cases, have beneficial effects (Smithard, 2002). Strategies for dealing with such negative effects may involve plant breeding, processing or specific treatments to ameliorate the effects of specific activities.

After a century of technical progress and huge practical experience in the control of protein nutrition in poultry production, procedures differ quite widely in different economies but are generally advanced and appropriate for different production systems. The quest for greater efficiency and for meeting the challenge of a changing industry however maintains an active research interest in this field. In industries where the supply and/or quality of protein feedstuffs is a problem, quite simple tables of requirements can be used and technical effort invested in controlling and improving ingredient quality. In industries where feed supply is more assured, amino acid levels can be adjusted to meet the requirements for different markets and to ensure maximum profitability for the whole enterprise. In all cases requirements and feed ingredients need to be described on the same scale and this scale needs to be additive when applied to feed mixtures. Existing technology makes this possible although the quality of data available to individual producers can often be improved. Methods of calculating amino acid responses through modelling are increasingly available although their uptake into the practical industry is proving to be slow. By using such methods protein and amino acid levels can be controlled to influence bird performance and to meet the overall objectives of the business. Nitrogen, together with phosphorus, is increasingly seen as an environmental pollutant and legal constraints on its use and disposal are applied in some countries. This problem is resolved increasingly at the level of the overall agricultural system but some interest in the use of low protein diets has been investigated as part of such a resolution. High nitrogen levels in feeds can also lead to production problems such as wet litter in broilers and turkeys leading to carcass blemishes and reduced fertility in broiler breeders.

The current immediate need is to ensure that best practise and the best data are widely available and applied in the industry. In the future it appears that ensuring a continuing supply of good quality protein feed ingredients is likely to be the highest priority in this field. Already some economies, for example Europe, are trying to reduce dependence on imported ingredients by extending the use of home-grown crops. The development of synthetic amino acid, and perhaps protein, sources is likely to continue and some potential new ingredients, for example insect meal (Józefiak and Engberg, 2015), have already been identified. But with continued growth in demand for poultry products set to soar the provision of adequate feeds of all kinds is likely to be the number one priority (Van der Aar et al., 2016).

\section{Energy}

Today, in the early $21^{\text {st }}$ century and after 100 years of WPSA work, economic control of the energy level in poultry feeds and consideration of future sources of feed energy are two of the dominant topics in poultry nutrition. However 100 years ago this was not so; the energy content of feeds being ensured simply by the inclusion of high levels of cereals. Thus in the proceedings of the $1^{\text {st }}$ World's Poultry Congress held in 1921 the word 'energy' scarcely appears in papers on feeding. The situation changed only slowly and in 1939, writing on the 'Practical Nutritive Requirements of Poultry', H.W. Titus uses the word energy only twice as a general descriptor of types of feed. Even by 1954 when the first Nutrient Requirements of Poultry was published in America by NAS-NRC 
no mention at all is made either of the energy content of feedstuffs or of energy in tables of nutrient requirements.

Energy research had been proceeding apace in farm animals since the end of the $19^{\text {th }}$ century. This was driven in part by the need to design controlled rations for producing cattle and pigs; a need which didn't arise in poultry fed ad libitum. In poultry the main response to dietary energy level is in feed intake and the choice of a practical level is largely an economic problem. The practical emphasis is on describing feeds as energy sources rather than defining energy requirements for productive purposes.

Although some earlier reports can be quoted, the first major investigation of the Metabolisable Energy (ME) content of poultry feedstuffs was a programme of work at the Texas Agricultural Experiment Station reported by Fraps et al. (1940). This same group also proposed and produced data for a system of Productive Energy (PE) for growing chicks using comparative slaughter techniques. The PE system was quite widely used in research although the level of practical application is unknown. However, after a few years several groups reported that $\mathrm{ME}$ determination was quicker, cheaper and more accurate than the determination of PE and since that time ME has been the standard energy system in both poultry research and in the feed industry. Technical work has been mainly concerned with different methods of determining and predicting ME values for the formulation of least-cost mixed feeds.

Metabolisable energy is determined in energy balance experiments with many variations of technique in different laboratories. In the 1950's and 60's substitution of test ingredients for starch or for a basal feed and the use of total excreta collection versus the use of digestion markers were the major procedural issues being discussed. The use of a correction for differences in nitrogen retention during experiments was also widely debated. However in spite of these uncertainties many good experiments were reported and energy tables of feed composition started to appear based on apparent metabolisable energy corrected to zero nitrogen retention (AMEn). The evaluation of fats presented particular problems but these could be overcome for practical purposes by evaluating fat digestibility. There was a sudden explosion of interest in this topic when Ian Sibbald from Agriculture Canada published an alternative, cheap and rapid assay for ME in poultry (Sibbald, 1976). This involved placing a small quantity of a single ingredient directly in the bird's crop by intubation and the use of fasted birds which were presumed to have an empty digestive tract at the start and end of the assay. Because small quantities of feed were used in the assay endogenous losses of energy from the digestive tract are relatively large and these losses must be determined and allowed for. This correction led to the assay becoming known as the True Metabolisable Energy (TME) method although this is not an essential feature. Sibbald's proposal led to a huge outpouring of research papers. In a list of references published 10 years after his original proposal, Sibbald (1986) listed 561 references on the subject, only five of which predated 1975. These extensive publications covered alternative assays which did not require intubation and other variations, many details of technique to overcome difficulties that were experienced when using the method and also many disputes about the validity of using a fasted bird to determine practical feeding values. The issues raised were not resolved in any general manner and a standard methodology has not appeared in this area. Variations on the Sibbald technique continue to be reported, presumably because the advantages of simplicity, cheapness and rapidity are still relevant. However when a standard method was proposed in Europe (Bourdillon et al., 1990) it was based on a conventional assay using fully fed birds. Such conventional approaches continue to be widely reported in the literature. The idea of a standardised method has not been widely accepted but the most widely used energy values used for feed formulation for poultry are still AMEn. 
Scientific discussion today is mainly concerned with the possibility of moving to a net Energy (NE) system for routine feed evaluation.

Working Group 2 of the European Federation of WPSA Branches has made two contributions to this area. The European Table of Energy Values for Poultry Feedstuffs was published in a $3^{\text {rd }}$ edition in 1989. This combined the experimental data from several laboratories in Europe. The table requires updating but it is still unique amongst tables of energy values in that equations are included for all feedstuffs which allow energy values to be corrected for variations in chemical composition. The Working Group also published and recommended to the (then) EEC an equation for predicting the $\mathrm{AME}_{\mathrm{n}}$ content of complete feeds from analytical data for crude protein, fat, starch and sugar content.

\section{Vitamins}

\section{DETERMINATION, DEFINITION AND ACTIVE FORMS}

The term 'vitamin' was proposed in 1912 by the Polish biochemist Casimir Funk to describe the essential function for life and amine structure of thiamin, a substance of his basic research. This expression was later also transferred to a group of organic compounds/substances which in low quantities were highly active and indispensable for many metabolic processes. They were considered not to be autosynthesised by higher animals (thus also by poultry) and by humans and therefore to be essential nutrients for life. We now know that this definition requires some reservations. For example it is known today that poultry are able to synthesise the vitamins D3 and C, niacin and choline partly or even completely; the carotines (pro-vitamins of vitamin A) are converted to vitamin A in different organs, indicating that for the supply with vitamin A it is sufficient to provide the primer substances. In contrast, it is difficult to observe in poultry any absorption of those vitamins which are synthesised microbially in the caeca (e.g. K3, B-complex). Thus this species is mainly dependant on a vitamin supply via the feed - as natural constituents of the feed ingredients and/or as supplements (feed additives).

The list of substances regarded as vitamins for poultry is as follows:

- Fat soluble vitamins: vitamin $\mathrm{A}$ (retinol), vitamin $\mathrm{D}_{3}$ (cholecalciferol), vitamin $\mathrm{E}$ (tocopherol), vitamin K (menaquinone).

- B-complex vitamins: thiamin, riboflavin, niacin, pantothenic acid, pyridoxine, folic acid, biotin, cobalamin (vitamin $\mathrm{B}_{12}$ ), choline.

These substances are not always, or only active, in the forms present in the diet but may be modified metabolically to other or more active forms. For instance, vitamin A performs many important functions as retinoic acid and vitamin D needs to be converted to its main active form 1,25-dihydroxycholecalciferol, sometimes called vitamin $\mathrm{D}_{3}$ hormone (DeLuca, 1974; 1988). Vitamin C (ascorbic acid) is not included in the official list of poultry vitamins though it is a useful supplement under stressful conditions when normal internal synthesis may become inadequate.

\section{DETECTION OF VITAMINS}

The initial vitamin detection was that of vitamin A (retinol) by McCollum in 1913; the biochemical structure of retinol was determined by Karrer in 1931, as reviewed by Semba (2012). By the 1940s, all of today's known vitamins had been identified; the last substance of this new micronutrient group was cobalamin (vitamin $\mathrm{B}_{12}$ ) which had been isolated in 1948 in both USA and UK. With the identification of vitamin $\mathrm{B}_{12}$ 
the so called Animal Protein Factor in liver, fishmeal and in ruminant excreta was explained. Although vitamin D had been identified in 1932, it was not until the 1970s that the functional importance of its metabolites became understood (DeLuca, 1974). For the detection, isolation and identification of most of the vitamins the chicken served as the most important research animal. Similarly for the exploration of metabolic functions (vitamins A and D, Wisconsin University; pantothenic acid, riboflavin, folic acid, Cornell University; Vitamin K, Universities of Guelph and Davis).

\section{INTENSIVE PERIOD OF VITAMIN RESEARCH}

After the detection, isolation and synthesis of the individual vitamins, a period of intensive research with poultry followed with the main object of establishing of requirements. This was at a time when modern intensive poultry production was developing economic importance so these studies were mainly carried out with growing chickens and laying hens (egg production, reproduction) because of their economic importance. Subsequently other species were studied, especially turkeys. Early work in the 1940s and 1950s was concentrated at universities and institutes in USA and Canada. There was some time-delay during war and post-war years, so from around 1960 onwards, European scientific institutions including universities, national institutes and academies started to develop their own vitamin research based on poultry (mainly A.R.C. Poultry Research Centre, Edinburgh; I.N.R.A. Nouzilly, France; Institute for Animal Nutrition, Weihenstephan, FRG; SPOFA, Prague, Czech Republic; Institute for Animal Nutrition, Jena, ex. GDR).

Simultaneously new techniques for vitamin analysis were developed and the vitamin levels in feedstuffs were determined by analysis. In trials it became more and more common for metabolic parameters to be used as evaluation criteria (e.g. enzyme activities for evaluation of B-vitamins) along with the usual zootechnical parameters. The influence of vitamins on reproductive characteristics such as fertility, embryonic development, hatchability and early mortality as well as requirements for post-natal performance were important topics for investigation and have been summarised (amongst many others) by Landauer (1961). Studies with synthetic and semi-synthetic diets allowed the description of vitamin deficiency disorders. In some disorders, interactions involving the lack or undersupply of several micro-nutrients, vitamins and trace minerals, needed to be considered. Good examples for this phenomenon are: dermatitis (niacin, vitamin A, folic acid, pantothenic acid, zinc ) and perosis (choline, vitamin $\mathrm{B} 12$, folic acid, manganese).

\section{DISEASE SYNDROMES RELATED TO VITAMINS}

There are characteristic signs of vitamin deficiencies in poultry, such as curled toe paralysis (riboflavin), dermatitis (niacin and others), encephalomalacia (vitamin E), rickets (vitamin $\mathrm{D}_{3}$ ), polyneuritis (thiamin). Once feed supplementation with synthetic vitamins became commonplace these disorders became much rarer in the field. However, new disorders related to vitamins have appeared as a result of continued increases in genetic performance potentials, the application of energy- and nutrient-rich diets, the use of imbalanced formulations as well as intensive housing systems for poultry. These conditions have included fatty liver syndrome in laying hens, the fatty liver and kidney syndrome (FLKS) in broiler chicks, skeletal disorders e.g. tibial dyschondroplasia (TD) and others. The explanation of the causes for the occurrence of FLKS and the involvement of biotin was established by Whitehead et al. (1976). At that time biotin was not a routine poultry supplement, partly because of its high cost. Subsequent studies showed the poor availability of this vitamin in some common feed ingredients (e.g. wheat) contributed to the problem and multidisciplinary studies 
established the full aetiology of the disorder (Whitehead, 2000). The subsequent use of biotin as a routine feed supplement for broilers led to larger-scale industrial synthesis and marked reduction in cost. For TD, prevention could be obtained by feeding the metabolically-active forms of vitamin $\mathrm{D}_{3}$, especially 1,25-dihydroxycholecalciferol (Edwards, 1990; Rennie et al., 1993).

\section{FURTHER FUNCTIONS RELATED TO VITAMINS}

Initially vitamin supply was mainly aimed at safeguarding optimal performance including lowest morbidity and mortality. Further criteria, where dosages above the normal nutritive requirements were used, for example for an improvement in immunological status (Leeson and Summers, 2001; Whitehead, 2000; Butcher and Miles, 2011). Investigations on these subjects started decades ago and are still ongoing at present. Promoting effects of vitamins $A$ and $E$ on the status of immunisation were confirmed mainly in investigations with broilers; for example increased vitamin E supplements promote immunisation against coccidiosis. For other additives (e.g. carotenoids, vitamin C) improved immunocompetence is also claimed. Under stressors such as heat the autosynthesis of vitamin $C$ by poultry is insufficient and supplements are needed to help alleviate that problem.

Increased vitamin supplementation to improve accumulation in eggs (Naber, 1993) and poultry meat (Weber, 2001) has advantages for human health. For several vitamins it is known that the concentration in the egg can be influenced by its levels in the feed. In this context it appears to be important that the transfer - rate from feed to egg is significantly different between vitamins (between $5-10 \%$ for folic acid and $60-80 \%$ for vitamin A) and that the transfer-rate in general declines with increasing dosage of vitamins significantly (Naber, 1993). It is known that several vitamins are incorporated into eggs by specific vitamin-binding proteins. Plasma concentrations of these proteins can have maximal values and this limits the total incorporation of these vitamins into eggs (White et al., 1986). In poultry meat increased vitamin $\mathrm{E}$ additions improve the oxidation stability of the fat content and conserve the colour of the meat.

\section{REQUIREMENTS AND SUPPLY OF VITAMINS}

The National Research Council (NRC) of USA first published in 1944 a monograph on energy and nutrient requirements of poultry. Already at that time vitamins were an important part of those recommendations. The latest version is the $9^{\text {th }}$ revised edition of Nutrient Requirements of Poultry (NRC, 1994). Further scientific recommendations concerning vitamin requirements have been published by Agricultural Research Council of Great Britain (ARC, 1975), Institute National de la Recherche Agronomique (I.N.R. A.), France (1981), Committee of Nutrient Requirements of the Society of Nutrition Physiology in Germany (GfE, 1999; 2004) and by the Polish Academy of Sciences (PAN, 2005). The subject of requirements and supply of vitamins is also dealt with in a number of books. The first edition of the 'The Scientific Feeding of Chicken' by Titus (1941) was followed by later editions, the $4^{\text {th }}$ edition appearing in 1961 . The topic of vitamins was treated in great depth by Scott, Nesheim and Young in their book title 'Nutrition of the Chicken ' (1st edition 1960). Leeson and Summers (2001) updated this book in their $4^{\text {th }}$ revised edition of 'Scotts Nutrition of the Chicken'. In Europe among others the following book titles need to be mentioned as they gave vitamins in poultry nutrition a sufficient scientific and practical importance: Jeroch (1972), Larbier and Leclercq (1994) and Vogt (1957).

The last NRC Requirements (1994) are often still cited as a standard source concerning vitamin recommendations. However, they are now considerably out of date as Leeson (2007) and Jeroch (2011) have shown. Those recommended figures are too low for an 
optimal supply of poultry under today's production conditions and they are too vague. The bases of the NRC requirements are mainly older investigations involving poultry with much lower performance levels than are currently possible. Practical recommendations therefore require additional safety margins which the NRC (1994) recommendations do not take into consideration. The vitamin A requirement of the laying hen according to NRC (1994) is $3000 \mathrm{IU} / \mathrm{kg}$ in mash feed; Leeson and Summers (2005) and Whitehead (1998) are recommending 8000 IU per kg or 12000 IU per kg feed respectively. The consideration of safety margins is necessary to take into account the following factors: variable contents in feedstuffs, vitamin losses during storage or processing, environmental factors, feed factors, stressors, antagonists, availability, performance changes and others.

In the early days of poultry production, beneficial effects were attributed to a range of feed ingredients of plant, animal or microbial origin. Subsequent information has suggested that these effects were largely attributable to the vitamin content of these ingredients. Examples are grain germs and maize germ oil (sources of $\beta$-carotene, vitamin $\mathrm{E}$, vitamins of $\mathrm{B}$-complex except $\mathrm{B}_{12}$ ); dried beet pulp (source of vitamins of B-complex except $\mathrm{B}_{12}$ ); yeast (vitamins of $\mathrm{B}$-complex except $\mathrm{B}_{12}$, vitamin $\mathrm{D}_{2}$ after $\mathrm{UV}$ contact); fish oil (vitamins $\mathrm{A}, \mathrm{D}_{3}, \mathrm{~B}_{12}$ ); dried fish soluble (vitamins of B-complex).

After the discovery of the individual vitamins, identification of their chemical structure and first technical solutions for synthesis the industrial production was rapidly developed and installed (chemical synthesis; fermentation or isolation from material of plant-/animal origin). Thus the new technical products replaced the specific feedstuffs that were used in the past as vitamin sources. The commercial supplements were treated and formulated in a way that guaranteed good criteria for practical application and effective incorporation into feed to give optimal mixing characteristics, high stability and good bioavailability. If these industrial vitamins ever become banned for use in organic diets in the future which is in discussion - the mentioned natural ingredients mentioned earlier would be alternative sources of many vitamins, but with many uncertainties and problems, for instance big variations in contents, highly variable availability and stability, high costs and potentially microbial contamination.

\section{CONCLUSIONS REGARDING VITAMINS}

Poultry production has benefitted greatly from the rapid advances in vitamin knowledge over the last 100 years. Poultry have also figured prominently in vitamin research as test animals. Today there is good knowledge on vitamin feeding of commercial poultry to optimise performance characteristics and also the health and welfare of the birds. However, changes in genetic performance of birds, new vaccination and health requirements and changes in management procedures may have implications for vitamin supply in the future. There will thus be a continuing need for trials using new methods of biochemical and physiological evaluation under practical situations. Further progress at the field of vitamins in modern poultry production requires more interdisciplinary research, both nationally and internationally.

\section{Minerals}

In birds, as in all animal species, minerals are required for the formation and the replacement of the skeleton, as parts or activators of enzymes and hormones, and for the maintenance of osmotic homeostasis and acid-base balance. Besides these basic functions, eggshell formation in laying birds also requires specific metabolisms of calcium $(\mathrm{Ca})$, phosphorus $(\mathrm{P})$ and carbonate ions. In intensive poultry production, the 
metabolic activity of birds is very high. A laying hen will deposit in eggshell during one year of production about 40 times the calcium present in its own skeleton; in broilers, the body content of $\mathrm{Ca}$ and $\mathrm{P}$ increases more than 60 times during its six weeks of life. So it is not surprising that thousands of studies related to the metabolism and the requirements of inorganic elements in poultry species, especially $\mathrm{Ca}$ and $\mathrm{P}$, have been conducted in the past 100 years, with a large increase after the 1960's. The following sections try to identify what were the most important innovations during this long and fascinating period.

\section{CALCIUM AND PHOSPHORUS NUTRITION IN GROWING BIRDS}

For many years, it was accepted that the requirements of growing chicks were covered with diets containing about $1 \% \mathrm{Ca}$ (from an highly available source such as dicalcium phosphate) and $0.5 \%$ of available $\mathrm{P}$, assuming that the phosphorus contained in grains as phytates (identified in 1855) was almost unavailable for growing birds. This hypothesis led to the incorporation of large amounts of inorganic phosphates in diets. These mineral sources are rather expensive, coming from non-renewable sources and partly responsible of the increased P load in the environment, less and less acceptable after the 1980's.

Three discoveries have deeply modified this situation. The first one originated from the measurement of the phytase activities in the cereal grains. As early as the 1940's, it was shown that the ratio between the extreme values of these activities were at least 3:1 in the order: rye and wheat $>$ barley $>$ oats $>$ corn and sorghum. Although these plant enzymes are probably less active in the chicken crop, due to its low $\mathrm{pH}$, it was clearly demonstrated that the plant phosphorus availability for young chicks, estimated by bone mineralisation, was rather high (between 50 and 70\%) in wheat, triticale and barley but less than $25 \%$ in corn, leguminous grains, soya meal and rapeseed meal (Hoshii and Yoshida, 1977; Sauveur, 1983). Taking these values into account allowed decreased use of inorganic phosphates and favoured the introduction of wheat or triticale at the expense of corn in poultry rations. However, these plant phytases are not thermostable; their activities are thus drastically decreased or even destroyed in heat treatment of diets.

The second important step was the use of exogenous microbial phytases, the interest of which was first shown by Nelson et al. (1971). Before the 1980 's, it was considered that the use of microbial phytases would be restricted to areas where financial penalties were imposed on excessive phosphorus levels in effluents from intensive pigs and poultry units. The first phytase feed enzyme commercially available was produced in Netherlands (from Aspergillus niger), and was indeed largely a response to local legislation focused to limit the phosphorus pollution in the environment (Simons et al., 1990). Today, the addition of microbial phytase, has been shown to enhance protein and energy utilisation and perhaps phosphorus solubility in the excreta, is almost universal worldwide. This global use of phytase in poultry feeds has more recently conducted to the third main innovation, namely a simultaneous decrease of $\mathrm{Ca}$ and $\mathrm{P}$ levels in diets.

Indeed, recent studies have shown that, when microbial phytase is used, relatively low levels of non-phytate $\mathrm{P}$ can allow optimal growth if the $\mathrm{Ca}$ concentration is simultaneously reduced. As a precaution, indicators of bone mineralisation should be used to determine the more adequate low levels of $\mathrm{Ca}$ and $\mathrm{P}$ for each level of phytase added (Letourneau-Montminy et al., 2010). This new way of decreasing the amounts of $\mathrm{P}$ losses into the environment may contribute to strengthening the sustainability of the poultry production in the future.

Starting in the 1940's, different approaches were tried in different parts of the world for determining the availability of $\mathrm{P}$ from different feed raw materials and later also for determining the efficiency of added phytase (Shastak and Rodehutscord, 2013). Because 
this limited much of the between-institution comparisons of results and compilation of feedstuffs tables, WPSA Working Group 2 (Nutrition) started an initiative with the aim of harmonising $\mathrm{P}$ evaluation in poultry. As a result, the Working Group recently suggested a standard protocol for the determination of $\mathrm{P}$ availability in poultry which is based on the measurement of precaecal P digestibility in broilers (WPSA, 2013).

\section{CALCIUM AND PHOSPHORUS NUTRITION IN LAYING HENS}

The presence of a specific, easily mobilised bone in some parts of the skeleton of adult female birds was shown from the beginning of the $20^{\text {th }}$ century. Known as medullary bone, it appears a few days before the first ovulation, simultaneously with the increase in concentration of blood Ca bound to lipoprotein. A few years later (in the 1930's), it was demonstrated that a minimum $\mathrm{Ca}$ dietary level was required to maintained ovulation in laying hens. Suppressing any Ca supply induced a cessation of lay after 8 to 14 days, with or without a previous appearance of some shell-less eggs. Numerous studies have shown that laying rate and shell thickness increase with calcium intake up to 3.5 to $4.5 \mathrm{~g} /$ hen/day, depending on both layer strain and egg production level. Two important scientific contributors, Simkiss and Taylor, were particularly active up to the 1970's in the understanding of Ca metabolism in laying hens (e.g. Simkiss, 1967; Taylor, 1970).

Several important studies conducted during the 1970's have revised the Ca needs of laying hens. First, it was demonstrated that hens present a specific appetite for calcium in relation to egg formation. This appetite appears some days before the sexual maturity and, on a short time basis, on each egg-forming day, precisely between 8 and 14 hours after the previous oviposition (Mongin and Sauveur, 1974), i.e. just before and at the start of eggshell deposition. Moreover, duodenal and jejunal $\mathrm{Ca}$ absorption were shown to increase during eggshell formation (Hurwitz and Bar, 1965). The most important application of these results was the introduction of coarse particulate calcium in practical diets. As first demonstrated by Scott and Mullenhoff (1970), this practice favours the expression of the calcium appetite and calcium storage in the crop, resulting in less bone mobilisation and an increase in eggshell strength (review by Nys, 2001).

Also during the 1970's, it was shown that bone mobilisation (revealed by a sharp increase in plasma inorganic $\mathrm{P}$ level and by $\mathrm{P}$ excretion) occurred during eggshell formation, precisely between 14 and 22 hours after the previous oviposition. A separate provision of dietary $\mathrm{Ca}$ reduced this bone mobilisation at night. According to Sauveur and Mongin (1983), the higher the duodenal-soluble Ca content during egg-shell formation, the lower the bone mobilisation and phosphoraemia and the higher the eggshell deposition. These results confirmed the interest of separate $\mathrm{Ca}$ feeding and relatively low dietary P levels for eggshell formation. Nevertheless, a minimum level of nonphytate $\mathrm{P}$ is always necessary for bone restoration. Decreased dietary $\mathrm{P}$ concentration according to a phase feeding programme can also be beneficial during the egg production period.

\section{ACID-BASE BALANCE AND DIETARY ELECTROLYTES}

Mongin and Sauveur in France have carried out many studies on acid-base balance in birds, both layers and broilers. Mongin (1968) was the first to show clearly that egg shell formation induced a metabolic acidosis in laying hen (characterised by a large drop in $\mathrm{pH}$ and bicarbonate concentration in blood) buffered by pulmonary hyperventilation. Any excess of dietary acidity or acidogenic anions such as chloride decreased eggshell strength while increasing albumen Haugh Units (a result firstly obtained by Hall and Helbacka, 1959). Such findings had numerous practical fallouts, principally the recommendation to limit the dietary chloride level to $1.2 \mathrm{~g} / \mathrm{kg}$ and to adjust the 
sodium level (Na) with bicarbonate or sulphate. Mongin and Sauveur (1977) developed the concept of dietary electrolyte balance (DEB $=\mathrm{Na}^{+}+\mathrm{K}^{+}-\mathrm{Cl}^{-}$, where concentrations of all ions are expressed in $\mathrm{mEq} / \mathrm{kg}$ of diet). Sauveur and Mongin (1978) showed that, in absence of deficiencies, the dietary electrolyte balance could vary over the range 160-360 $\mathrm{mEq} / \mathrm{kg}$ of feed without adverse effect on egg shell thickness.

In growing birds, the early interest of practical poultry breeders in salt was based on toxicity. From the end of the $19^{\text {th }}$ century, it was known that a small excess of dietary sodium was sufficient to cause death. The occurrence of possible sodium and chloride deficiencies with corn based diets appeared during the 1920's and it was established in the 1930 's that the sodium requirement was satisfied with $4-5 \mathrm{~g}$ salt $/ \mathrm{kg}$ diet. Increasing this level resulted into higher water consumption, liquid droppings and wet litter, causing skin and feet injuries. The research team in Cornell University conducted by Nesheim and Leach during the 1960's showed that excess dietary chloride had detrimental effect on the weight gain and incidence of tibial dyschondroplasia, unless balanced equimolarly with sodium or potassium supplied with a metabolisable anion (Nesheim et al., 1964). Mongin and Sauveur (1977) established that optimal growth and the lowest incidence in tibial dyschondroplasia were obtained when the DEB was maintained close to $250 \mathrm{mEq} / \mathrm{kg}$ diet. In further studies, the concept of DEB was extended to include other ions such as magnesium, phosphate and sulphate. Such control of acid-base homeostasis through monitoring of specific dietary minerals has found special applications in hot countries where heat stress and panting induced respiratory alkalosis.

Before concluding, it is pertinent to recall the important collaborative work conducted during the 1980's by the mineral Sub-Committee of Working Group 2 (Nutrition) to provide mineral recommendations accepted in all European countries for all poultry species (Vogt et al., 1981; 1984; 1985).

\section{TRACE ELEMENTS}

Other minerals are important in nutrition. Magnesium is required for some metabolic functions but sufficient amounts are contained in practical feed ingredients so it does not appear as a routine feed supplement. However, diets are regularly supplemented with other elements, such as iron, copper, manganese, zinc, selenium and iodine. The supplements for these elements were traditionally in the form of inorganic salts. The availabilities of the elements from these salts could be variable and were not always well documented; leading to uncertainties over requirements, so there was a tendency to overformulate to avoid the possibility of deficiency. This practice was not only wasteful but led to environmental contamination from elevated concentrations in excreta.

This situation has been improved in recent years by providing minerals in organic form, as part of organic chelates, complexes or bound to amino acids or other molecules. Absorbability of minerals from these organic forms is considerably higher than from inorganic molecules, due in part to sometimes different mechanisms of absorption. This has led, as in the case of selenium, to more efficient incorporation into tissues and enzymes that utilise this element. The beneficial consequences resulting from the use of organically-bound minerals include lower mineral concentrations in diets, less environmental contamination and less risk of adverse interactions of these minerals with other dietary components. 


\section{Other feed additives}

\section{ANTIBIOTICS}

Antibiotics were defined originally as the range of substances derived from bacterial sources (microorganisms) that control the growth of or kill other bacteria. Subsequently synthetic antibiotics, usually chemically related to natural antibiotics, have been produced. During ancient times Greeks and Indians used moulds (http://www. experiment-resources.com/history-of-antibiotics.html) to treat infections. The history of modern antibiotics started with the discovery of penicillin by Alexander Fleming in 1928. The growth-promoting effect of low levels of antibiotics in animal feeds was first described in the late 1940s when chickens fed fermentation waste from tetracycline production grew more rapidly than controls (Stokestad and Jukes, 1949; cited by Barton, 2000). Since then effects of feeding sub-therapeutic levels of a wide range of antibiotics have been described and the use of antibiotic growth-promoters (AGPs) became common practice, particularly in the intensive animal production. The mode of action of AGPs is attributed to their effects on the intestinal bacteria flora, thereby also protecting the birds from intestinal infections, especially necrotic enteritis caused by toxin-producing Clostridia species (Al-Sheikhly and Truscott, 1977).

However, reports of bacterial resistance in food animals soon appeared as reviewed by Dibner and Richards (2005). Early concerns also about the development of antibiotic resistance in human pathogens resulted in Swann (1969) proposing in a report to the British Parliament the banning of sub-therapeutic antibiotic use in animal feeds. It was recommended that antibiotics for use in animal feeds should be restricted to those with little or no therapeutic application in man or animals and which would not impair the efficacy of therapeutic antibiotics because of cross-resistance. In response to the report, a number of countries (including the UK, European countries and Australia) removed penicillin and tetracyclines, at that time the most widely used AGPs, from the approved list. However, the USA did not respond in this way and was still in 2012 using feed antibiotics, including penicillin (Fairchild and Hofacre, 2012), despite the fact that antimicrobial resistance today clearly remains an ecological issue affecting individuals, entire communities and hospitals (Andremont et al., 2011). The USA, FDA (2012) recommended to farmers that certain antibiotics should not be used for so-called 'production' purposes, such as to enhance growth or improve feed efficiency in an animal. Working Group 2 (Nutrition) highlighted the subject in its 1995 Symposium, when Lange and Ek, (1995) anticipated a future 'post-antimicrobial era'.

Within the EU there has been a successive withdrawal of approval for antibiotics starting 1997 to the last ban from Jan $1^{\text {st }} 2006$ (Castanon, 2007). Scientists are now searching for alternatives to antibiotics that would keep farm animals healthy and growing without posing a risk to human health (Huyghebaert et al., 2011).

\section{ANTICOCCIDIALS}

Swedish farmers voluntarily abandoned the use of feed antibiotics as early as 1984 under direction from the Commission on Antimicrobial Feed Additives (COM, 1997) without the occurrence of any serious problems or loss of production efficiency. This was due to the fact that ionophore anticoccidials were found to have effects similar to feed antibiotics on bacteria, especially against Clostridium perfringens, the causative agent of necrotic enteritis (Elwinger et al., 1998; Martel et al., 2004; Williams, 2005). Coccidiostats were at that time not classified as antibiotics and because there is limited use of similar substances in human medicine they were not subjected to the same criticism. Within the EU anticoccidials are considered as feed additives and may be fed in feed to prevent parasitic infections caused by Eimeria spp. without veterinary 
prescription. According to Williams (2002) the major breakthrough of anticoccidials is attributed to Levine (1939) who demonstrated the anticoccidial effect of sulphanilamide. Since then a large number of anticoccidial drugs have been introduced. However, with time increased resistance to all of them has been described in different parts of the world (Abbas et al, 2011). As an exception the ionophore narasin has been used in Sweden since 1984 where no signs of such an increase have so far been observed, according to a surveillance programme in force since 1999 (SJVFS, 1998).

Within the EU, anticoccidials were planned to be phased out in 2012 (EC, 2003) and the Commission had to submit to the European Parliament and the Council before 1 January 2008 a report on the use of these substances as feed additives and available alternatives, accompanied, where appropriate, by legislative proposals. This report (EC, 2007) concluded that at the present time, the use of coccidiostats as a preventive measure for the control of coccidiosis in modern poultry production was essential and alternatives currently did not offer the same advantages. The EU Commission believed that it was inappropriate to change the existing situation at that time and that the existing system was well placed to deal with the current situation, providing as it did a high level of safety for consumers and adequate protection for animal health and welfare and the environment as well as a fair framework within which operators could do business. The Commission was to continue to monitor the development of new substances and techniques for the prevention of the diseases. The holder of authorisation (the industry) for such feed additives had to plan and execute a post-market monitoring programme on the resistance of bacteria and Eimeria species. Examples of two such surveillance programmes are described by Jeffers (2012). The future status of anticoccidial drugs is uncertain at this moment, their current status as feed additives may be maintained or new legislation and phasing-out of these drugs as feed additives could be proposed. Actual and forthcoming information of the obtained regulations can be found on the website of the European Commission animal nutrition feed additives (http://ec.europa.eu/ food/safety/animal-feed/feed-additives/).

Because of drug resistance, the reliance upon chemotherapy is uncertain and access to future alternatives to anticoccidials seems necessary. Vaccine strategies today are based upon live attenuated precocious lines of Eimeria (Williams, 2002). The large-scale manufacture of live vaccines, especially attenuated vaccines, is expensive, complicated and conflicting with animal welfare since it includes infection and killing of large numbers of birds. An anticoccidial vaccine composed of protective antigens, either native (Sharman et al., 2010) or recombinant (McDonald and Shirley, 2009) has therefore been pursued as an alternative to live vaccines and the problems and costs associated with them. Vaccination is today predominately carried out with laying hens whereas broiler production is mainly relaying on coccidiostats.

The withdrawal of anticoccidials would potentially increase the risk of intestinal clostridia infections occurring. This possibility further highlights the importance of finding alternative preventative measures (Dahiya et al., 2006; Huyghebaert et al., 2011). However, the era of AGPs has definitely ended. Anticoccidials are today partly replaced by live vaccines but their use will continue, especially for broilers in the absence of effective alternatives that can also be effective against clostridial infections.

\section{ENZYMES}

The earliest report on the use of exogenous enzymes in feed was by Clickner and Follwell (1925) who found that adding an enzyme preparation from Aspergillus improved pullet performance. However, it was not until the 1980s that enzyme use took off with the development of a range of enzymes that had beneficial effects on specific feed ingredients. These effects were mainly associated with degradation in the digestive 
system of non-soluble polysaccharides (NSP). This had the effect of decreasing the viscosity of intestinal contents, thus allowing the more efficient digestion and absorption of nutrients. For instance, the lower nutritive value of barley was associated with its $\beta$-glucan content. Thus $\beta$-glucanase enzymes have been effective in improving the nutritive value of barley (Hesselman and Aman, 1986). Other cereals such as wheat and rye contain NSPs based on arabinoxylans. Accordingly, the use of xylanase enzymes has improved the nutritive values of diets containing these cereals (Petterson and Aman, 1988). Protease enzymes are effective with protein sources, improving nutritive value and degrading anti-nutritive factors such as trypsin inhibitors.

The use of phytase to liberate phytate-bound $\mathrm{P}$ has been described earlier in connection with enhancing phosphorus and calcium availability. It has been demonstrated further that use of phytase can increase the availability and digestibility of other minerals and amino acids (Bryden, 1999; Ravindran et al., 2000). Studies have shown that, in general, dietary phytase supplements in the range 500-750 FTU/kg are sufficient to maximise liberation of P. However, it has been shown that 'superdosing' with much higher concentrations of phytase, up to and beyond $10000 \mathrm{FTU} / \mathrm{kg}$ can have benefits on various aspects of performance (weight gain, improved feed conversion and meat yield) beyond that which can be explained by improved P availability alone (Shirley and Edwards, 2003). The precise mechanisms for this effect are currently unclear.

\section{OTHER FEED ADDITIVES}

As a result of the banning of antibiotic growth promoters, considerable interest has arisen in the use of other types of additive that might promote growth or provide other health benefits. Probiotic and prebiotic preparations containing non-pathogenic bacteria and different oligosaccharides have been marketed with the aim of influencing gut microbiota in beneficial ways. Plant extracts have also been investigated extensively. Essential oils from herbs such as oregano, garlic, thyme, rosemary and sage have been assessed. Extracts from other plants have also been tried. Beneficial effects have been reported from many of these. The responses in growth promotion are usually less than previously seen with AGPs and difficulties arise with the ill-defined compositions of some extracts. Nevertheless, products are now being marketed with specific compositions of essential oils or other extracts from plants that show some benefits for poultry performance.

In response to concerns over bacterial contamination of diets, organic acids such as propionate are now also regularly added to diets.

\section{Feed technology}

Much has changed since the early days when poultry were fed by scattering grains on the ground. The next step was to combine ingredients into complete feeds in mash form. Today the procedures are much more complex. Preparing mixed feeds into pellets by steam processing provided performance and health benefits by improving nutritive quality, decreasing bacterial contamination and facilitating greater feed intake. Latest technology now includes the use of extruders or expanders prior to pelleting. In the latter, feed is forced into an outlet along with the application of steam, resulting in high temperatures over a short period. A disadvantage of high temperatures is that there can be degradation of some nutrients (e.g. vitamin K) or useful enzymes. For this reason, exogenous enzyme addition often takes place after pellet formation.

Feed formulation practices have also changed markedly over the years. An often 
laborious process has now been transformed by the introduction of linear programming and the use of computers.

\section{Conclusions and future directions}

It is often risky to attempt to predict where anything will go in the future and such is the case with poultry nutrition. The roles of individual nutrients are well-understood so future developments will probably lie more in the area of feed ingredients rather than specific nutrients. There is currently much interest in alternatives to soybean as protein sources, particularly ones that can be grown in colder climates. Will climate change allow expansion of soybean production into other parts of the world? Or will genetic changes bring about more nutritive feedstuffs? This has been shown possible by the breeding of cereals with enhanced amounts of oils, amino acids (e.g. lysine) or enzymes (e.g. phytase). However, cereal breeding is dominated currently by more commercial considerations such as ethanol production, including brewing, and bread and pasta making rather than poultry nutrition. Will more fundamental genetic modification (GM) result in beneficial changes in feed ingredients, and will this become more publicly-acceptable? The search is also likely to continue for other plant products and/ or extracts that may have useful properties. The face of poultry nutrition has changed markedly over the last 100 years and is likely to continue in the future, though the pace may be much slower.

\section{References}

ABBAS, R.Z., IQBAL, Z., BLAKE, D., KHAN, M.N. and SALEEMI, M.K. (2011) Anticoccidial drug resistance in fowl coccidia: the state of play revisited. World's Poultry Science Journal 67: 337-349.

AL-SHEIKHLY, F. and TRUSCOTT, R.B. (1977) The interaction of Clostridium perfringens and its toxins in the production of necrotic enteritis of chickens. Avian Diseases 21: 256-263.

ANDREMONT, A., MARC BONTEN, M., KLUYTMANS, J., CARMELIE, Y., CARS, O. and HARBART, S. (2011) Fighting bacterial resistance at the root: need for adapted EMEA guidelines. The Lancet Infectious Diseases 11: 6-8.

ARC (1975) The Nutrient Requirements of Farm Livestock, No. 1 Poultry. 153 pp (Agricultural Research Council, London).

BARTON, M.D. (2000) Antibiotic use in animal feed and its impact on human health. Nutrition Research Reviews 13: 279-299.

BOURDILlON, A., CARRE, B., CONAN, L., DUPERRAY, J., HUYGHEBAERT, G., LECLERCQ, B., LESSIRE, M., MCNAB, J.M. and WISEMAN, J. (1990) European reference method for the in vivo determination of metabolisable energy with adult cockerels: reproducibility, effect of food intake and comparison with individual laboratory methods. British Poultry Science 31: 557-565.

BRYDEN, W.L. (1999) Influence of microbial phytase on apparent ileal amino acid digestibility of feedstuffs for broilers. Poultry Science 78: 677-706.

BUTCHER, G.D. and MILES, R.D. (2011) Interrelationship between nutrition and immunity in commercial poultry. Proceedings of the $18^{\text {th }}$ European Symposium on Poultry Nutrition, October, Cesme-Izmir, Turkey, pp.154-162.

CARPENTER, K.J. (1994) Protein and Energy. A study of changing ideas in nutrition. (Cambridge University Press, Cambridge, UK).

CASTANON, J.I.R. (2007) History of the Use of Antibiotic as Growth Promoters in European Poultry Feeds. Poultry Science 86: 2466-2471.

CLICKNER, F.H. and FOLLWELL, E.H. (1925) Application of 'protozyme' by Aspergillus Orizae to poultry feeding. Poultry Science 5: 241-247.

COM (1997) Antimicrobial Feed Additives (Swedish Ministry of Agriculture, Stockholm).

DAHIYA, J.P., WILKIE, D.C., VAN KESSEL, A.G. and DREW, M.D. (2006) Potential strategies for controlling necrotic enteritis in broiler chickens in post-antibiotic era. Animal Feed Science and Technology 129: 60-88. 
DELUCA, H.F. (1974) Vitamin D: the vitamin and the hormone. Federation Proceedings 33: 2211-2219.

DELUCA, H.F. (1988) The Vitamin D story: a collaborative effort of basic science and clinical medicine. Federation of American Societies for Experimental Biology Journal 2: 224-236.

DIBNER, J.J. and RICHARDS, J.D. (2005) Antibiotic Growth Promoters in Agriculture: History and Mode of Action. Poultry Science 84: 634-643.

D'MELLO, J.P.F. (2003) Responses of growing poultry to amino acids, in: D'MELLO J.P.F. (Ed) Amino acids in animal nutrition, pp. 237-263 (CABI, Wallingford, UK).

EC (2003) Regulation (EC) No 1831/2003 of the European Parliament and of the Council.

EC (2007) European Commission review of the regulation of coccidiostats as feed additives - update 2007.

EDWARDS, H.M. (Jr) (1990) Efficacy of several vitamin D compounds in the prevention of tibial dyschondroplasia in broiler chickens. Journal of Nutrition 120: 1054-1061.

ELWINGER, K., BERNDTSON, E., ENGSTROM, B., FOSSUM, O. and WALDENSTEDT, L. (1998) Effect of antibiotic growth promoters and anticoccidials on growth of Clostridium perfringens in the caeca and on performance of broiler chickens. Acta Veterinaria Scandinavica 39: 433-441.

FAIRCHILD, B.D. and HOFACRE, C.L. (2012) The future of antibiotic use in poultry production. www. WATTAgNet.com, January: 28-29.

FRAPS, G.S., CARLYLE, E.C. and FUDGE, J.F. (1940) Metabolisable energy of some chicken feeds. Texas Agricultural Experiment Station Bulletin No. 589.

GfE (1999) Ausschuss fuer Bedarfsnormen, in: Empfehlungen zur Energie- und Naehrstoffversorgung der Legehennen und Broiler, 145 pp (DLG-Verlag, Frankfurt am Main).

GfE (2004) Empfehlungen zur Energie- und Naehrstoffversorgung der Mastputen. Proceedings of the Society of Nutrition Physiology 13: 199-233.

HALL, K.N. and HELBACKA, N.V. (1959) Improving albumen quality. Poultry Science 38: 111-114.

HESSELMAN, K and AMAN, P. (1986) The effect of $\beta$-glucanase on the utilization of starch and nitrogen by broiler chicks fed on barley of low or high viscosity. Animal Feed Science and Technology 15: 83-93.

HOSHII, H. and YOSHIDA, M. (1977) Phosphorus availability of 25 feed ingredients determined by bioassay on toe ash content. Japanese Poultry Science 14: 274-278.

HURWITZ, S. and BAR, A. (1965) Absorption of calcium and phosphorus along the gastrointestinal tract of the laying fowl as influenced by the dietary calcium and egg shell formation. Journal of Nutrition 86: 433438.

HUYGHEBAERT, G., DUCATELLE, R. and VAN IMMERSEEL, F. (2011) An update on alternatives to antimicrobial growth promoters for broilers. The Veterinary Journal 187: 182-188.

JEFFERS, T.K. (2012) Monitor efficacy of anticoccidial program. Feedstuffs 23: 1-3.

JEROCH, H. (1972) Vitamine, in: HENNIG, A. (Ed) Mineralstoffe, Vitamine, Ergotropika, pp. 264-387 (Deutscher Landwirtschaftsverlag, Berlin).

JEROCH, H. (2011) Recommendations for energy and nutrients of Layers. A critical review. Lohmann Information 46: 61-72.

JÓZEFIAK, D. and ENGBERG, R.M. (2015) Insects as poultry feed. Proceedings $20^{\text {th }}$ European Symposium on Poultry Nutrition, Prague, Czech Republic, pp. 75-81.

LANDAUER, L. (1961) The hatchability of chicken eggs as influenced by environment and heredity. (Storrs Agricultural Experiment Station, The University of Connecticut, Storrs, Connecticut).

LANGE, S. and EK, E. (1995) On putting the argument for banning or tightly controlling the use of antibiotics as feed additives. Proceedings of $10^{\text {th }}$ European Symposium on Poultry Nutrition, Antalya, Turkey, pp. 208218.

LARBIER, M. and LECLERCQ, B. (1994): Nutrition and Feeding of Poultry. (Nottingham University Press, Loughborough, GB,) 305 pp.

LEESON, S. (2007) Vitamin requirement: is there basis for re-evaluating dietary specifications? World's Poultry Science Journal 63: 255-266.

LEESON, S. and SUMMERS, J.D. (2001) Scott's Nutrition of the Chicken, $4^{\text {th }}$ ed., University Books, Guelph, Ontario, Canada, 591 pp.

LEESON, S. and SUMMERS, J.D. (2005) Commercial Poultry Nutrition, 3rd edition, (Nottingham University Press, UK), 398 pp.

LEMME, A. (2003) The 'Ideal Protein Concept ' in broiler nutrition, 1. Methodological aspects - opportunities and limitations. AminoNews ${ }^{T M} 4$ (1): 7-14, Degussa AG, Hanau, Germany.

LEMME, A., RAVINDRAN, V. and BRYDEN, W.L. (2004) Ileal digestibility of amino acids in feed ingredients for broilers. World's Poultry Science Journal 60: 423-437.

LERMAN, P.M. and BIE, S.W. (1975) Problems in determining the best levels of essential nutrients in feedingstuffs. Journal of Agricultural Science (Cambridge) 84: 459-468.

LETOURNEAU-MONTMINY, M.P. NARCY, A., LESCOAT, P., BERNIER, J.F., MAGNIN, M., POMAR, C., NYS Y., SAUVANT, D. and JONDREVILLE, C. (2010) Meta-analysis of phosphorus utilisation by broilers receiving corn-soybean meal diets: influence of dietary calcium and microbial phytase. Animal 4: 1844-1853. 
LEVINE, P.I. (1939) The effect of sulfanilamide on the course of experimental avian coccidiosis. Cornell Veterinarian 29: 309-320.

MACK, S., HÖHLER, D. and PACK, M. (2000) Evaluation of dose-response data and implications for commercial formulation of broiler diets. Proceedings of the Australian Poultry Science Symposium 82-878.

MARTEL, A., DEVRIESE, L.A., CAUWERTS, K., DE GUSSEM, K., DECOSTERE, A. and HAESEBROUC, F. (2004) Susceptibility of Clostridium perfringens strains from broiler chickens to antibiotics and anticoccidials. Avian Pathology 33: 3-7.

MCDONALD, V. and SHIRLEY, M.W. (2009) Past and future: vaccination against Eimeria. Parasitology 136: $1477-1489$.

MONGIN, P. (1968) Role of acid-base balance in the physiology of egg shell formation. World's Poultry Science Journal 24: 200-230.

MONGIN, P. and SAUVEUR, B. (1974) Voluntary food and calcium intake by the laying hen. British Poultry Science 15: 349-359.

MONGIN, P. and SAUVEUR, B. (1977) Interrelationship between mineral nutrition, acid-base balance, growth and cartilage abnormalities, in: BOORMAN, K.M. \& WILSON B.J. (Eds) Growth and poultry meat production, pp. 235-247 (British Poultry Science Ltd, Edinburgh, UK).

NABER, C. (1993) Modifying vitamin composition of eggs: a review. Journal of Applied Poultry Research 2: 385-393.

NELSON, T.S., SHIEH, T.R., WODZINSKI, R.J. and WARE, J.H. (1971) Effect of supplemental phytase on utilization of phytate phosphorus by chicks. Journal of Nutrition 101: 1289-1294.

NESHEIM, M.C., LEACH, R.M., ZEIGHER, T.R. and SERAFIN, J.A. (1964) Interrelationships between dietary levels of sodium, chlorine and potassium. Journal of Nutrition 84: 361-366.

NRC (1954) Nutrient Requirements of Poultry, Number 1, National Academy Press, Washington, D.C., 37 pp.

NRC (1994) Nutrient Requirements of Poultry, $9^{\text {th }}$ revised ed., National Academy Press, Washington, D.C., 155 pp.

NYS, Y. (2001) Recent developments in layer nutrition for optimising shell quality. Proceedings of $13^{\text {th }}$ European Symposium on Poultry Nutrition, Blankenberge, Belgium, pp. 45-52.

PAN (2005) Nutrient requirement of poultry, in: Nutrient Value of the Feedstuffs and Feeding Recommendations. $4^{\text {th }} \mathrm{ed}$., $135 \mathrm{pp}$. (Kielanowski-Institute for Animal Physiology and Nutrition, Jablonna/ Warsaw) (in Polish).

PESTI, G.M., VEDENOV, D., CASON, J.A. and BILLARD, L. (2009) A comparison of methods to estimate nutritional requirements from experimental data. British Poultry Science 50: 16-32.

PETTERSON, D. and AMAN, P. (1988) Effects of enzyme supplementation of diets based on wheat, rye or triticale on their productive value for broiler chickens. Animal Feed Science and Technology 20: 313-324.

RAVINDRAN, V., CABAHUG, S., RAVINDRAN, G., SELLE, P.H. and BRYDEN, W.L. (2000) Response of broiler chickens to microbial phytase supplementation as influenced by dietary phytic acid and non-phytate phosphorus levels. II. Effects on apparent metabolisable energy, nutrient digestibility and nutrient retention. British Poultry Science 41: 193-200.

RENNIE, J.S., WHITEHEAD, C.C. and THORP, B.H. (1993) The effect of dietary 1,25dihydroxycholecalciferol in preventing tibial dyschondroplasia in broilers fed on diets imbalanced in calcium and phosphorus. British Journal of Nutrition 69: 809-816.

SAUVANT, B., SCMIDELY, P., DAUDIN, J.J. and ST-PIERRE, N.R. (2008) Meta-analyses of experimental data in animal. Nutrition Animal 2: 1203-1214.

SAUVEUR, B. (1983) Bio-availability for poultry of plant-origin phosphorus. Methodological criticisms and results. Proceedings of 4th European Symposium on Poultry Nutrition, Tours, France, pp. 103-113.

SAUVEUR, B. and MONGIN, P. (1978) Interrelationships between dietary concentrations of sodium, potassium and chloride in laying hens. British Poultry Science 19: 475-485.

SAUVEUR, B. and MONGIN, P. (1983) Plasma inorganic phosphorus concentration during eggshell formation. II. Inverse relationships with intestinal calcium content and eggshell weight. Reproduction, Nutrition, Development 23: 755-764.

SCOTT, M.L. and MULLENHOFF, P.A. (1970) Dietary oyster shell and egg-shell quality. Proceedings of the Cornell Nutrition Conference, pp. 24-28.

SCOTT, M.L., NESHEIM, M.C. and YOUNG, R.J. (1960) Nutrition of the chicken, $1^{\text {st }}$ edition. (M.L. Scott and Associates, Ithaca, New York) $511 \mathrm{pp.}$

SEMBA, R.D. (2012) On the discovery of vitamin A. Annals of Nutrition and Metabolism 61: 192-198.

SHARMAN, P.A., SMITH, N.C., WALLACH, M.G. and KATRIB, M. (2010) Chasing the golden egg: vaccination against poultry coccidiosis. Parasite Immunology, 32: 590-598.

SHASTAK, Y. and RODEHUTSCORD, M. (2013) Determination and estimation of phosphorus availability in growing poultry and their historical development. World's Poultry Science Journal 69: 569-586.

SHIRLEY, R.B. and EDWARDS, H.M. (2003) Graded levels of phytase past industry standards improve broiler performance. Poultry Science 82: 671-680.

SIBBALD, I.R. (1976) A bioassay for true metabolisable energy in feedingstuffs. Poultry Science 55: 303-308. 
SIBBALD, I.R. (1986) The TME system of feed evaluation: methodology, feed composition data and bibliography. Technical Bulletin 4 E., (Animal Research Centre, Research Branch, Agricultural. Ottawa, Canada).

SIMKISS, K. (1967) Calcium in reproductive physiology (London, Chapman and Hall).

SIMONS, P.C.M., VERSTEEGH, H.A.J., JONGBLOED, A.W., KEMME, P.A., SLUMP, P., BOS, K.D., WOLTERS, M.G.E., BEUDEKER, R.F. and VERSCHOOR, G.J. (1990) Improvement of phosphorus availability by microbial phytase in broilers and pigs. British Journal of Nutrition 64: 525-540.

SJVFS (1988) In: Direction of compulsory surveillance control of coccidiosis in slaughter chickens, p 131 (Swedish Board of Agriculture, Stockholm) (in Swedish).

SMITHARD, R. (2002) Secondary plant metabolites in poultry nutrition, in: MCNAB, J.M. \& BOORMAN, N. K. (Eds) Poultry feedstuffs. Supply, composition and nutritive value, pp. 237-278 (CABI, Wallingford, UK).

STOKESTAD, E.L.R. and JUKES, T.H. (1949) The multiple nature of the animal protein factor. Journal of Biological Chemistry 180: 647-654.

SWANN, M.M. (1969) Use of Antibiotics in Animal Husbandry and Veterinary Medicine (H.M. Stationery Office, London).

TAYLOR, T.G. (1970) How an eggshell is made. Scientific American 222: 89-95.

TITUS, H.W. (1941) Quoted in: The scientific feeding of chickens (The Interstate, Danville, Illinois) $\left(4^{\text {th }}\right.$ Edition published in 1961).

U.S. FDA (2012) FDA News release. April 16, http://www.fda.gov/NewsEvents/Newsroom/ PressAnnouncements/ucm299802.

VAN DER AAR, P.J., DOPPENBERG, J. and KWAKERNAAK, C. (2016) Which feedstuffs will be used in the future? In: BURTON, E., GATCLIFFE, J. \& O'NEIL, H.M. and SCHOLEY,D. (Eds) Sustainable poultry production in Europe, pp. 103-111 (CABI, Wallingford, UK).

VOGT, H. (1957) Fuetterung des Gefluegels, in: SCHOLTYSSEK, S. (Ed) Gefluegel, pp. $216-311$ (Verlag Eugen Ulmer, Stuttgart).

VOGT, H., DEWAR, W.A., SAUVEUR, B. and SIMONS, P. (1981) Mineral requirements for poultry. Recommendations in European countries. World's Poultry Science Journal 37: 127-138

VOGT, H., DEWAR, W.A., SAUVEUR, B. and SIMONS, P. (1984) Mineral requirements for poultry. Mineral requirements and recommendations for adult birds. World's Poultry Science Journal 40: 183-187.

VOGT, H., DEWAR, W.A., SAUVEUR, B. and SIMONS, P. (1985) Mineral requirements for poultry. Mineral requirements and recommendations for growing bird. World's Poultry Science Journal 41: 252-258.

WEBER, G. (2001) Nutritional effects on poultry meat quality, stability and flavour. Proceedings of $13^{\text {th }}$ European Symposium on Poultry Nutrition, Blankenberge, Belgium, pp. 9-16.

WHITE, H.B., ARMSTRONG, J. and WHITEHEAD, C.C. (1986) Riboflavin-binding protein: concentration and fractional saturation in chicken eggs as a function of dietary riboflavin. Biochemical Journal 238: 671675.

WHITEHEAD, C.C. (1998) Vitamin interactions and requirements in poultry. $7^{\text {th }}$ International Symposium on Animal Nutrition, Kaposvar, Hungary, pp. 3-31.

WHITEHEAD, C.C. (2000) Nutrition: the integrative science. British Poultry Science 41: 5-15.

WHITEHEAD, C.C., BLAIR, R., BANNISTER, D.W., EVANS, A.J. and MORLEY JONES, R. (1976) The involvement of biotin in preventing the fatty liver and kidney syndrome in chicks. Research in Veterinary Science 20: 180-184.

WILLIAMS, R.B. (2002) Fifty years of anticoccidial vaccines for poultry 1952-2002. Avian Diseases 46: 775 802.

WILLIAMS, R.B. (2005) Intercurrent coccidiosis and necrotic enteritis of chickens: rational, integrated disease management by maintenance of gut integrity. Avian Pathology 34: 159-180.

WPSA (2013) Determination of phosphorus availability in poultry. World's Poultry Science Journal 69: 687698. 